\title{
Effects of ciliary muscle plasmid electrotransfer of $T N F-\alpha$ soluble receptor variants in experimental uveitis
}

E Touchard, C Bloquel, P Bigey, L Kowalczuc, L Jonet, B Thillaye-Goldenberg, M-C Naud, D Scherman, Y de Kozak, D BenEzra and F Behar-Cohen

Gene Therapy (2009) 16, 1058; doi:10.1038/gt.2009.89

Correction to: Gene Therapy (2009) 16, 867-873; doi:10.1038/gt.2009.43

Since the above publication the authors have noticed a spelling error; the correct spelling is

'Kowalczuk L' instead of 'Kowalczuc L'

The authors would like to apologize for any inconvenience this may have caused. 